\title{
Does Chinese Financial Market Information Promote Listed Manufacturing Firms' Productivity?
}

\author{
Fujun Lai ${ }^{1}$, Qian Wang ${ }^{2}$ and Qingxiang Feng ${ }^{3, *(1)}$ \\ 1 Chinese Academy of Finance and Development, Central University of Finance and Economics, \\ Beijing 100081, China; 2015110137@email.cufe.edu.cn \\ 2 School of Management Science and Engineering, Central University of Finance and Economics, \\ Beijing 100081, China; 2017211477@email.cufe.edu.cn \\ 3 Institute of Guangdong Hong Kong and Macao Development Studies, Sun Yat-sen University, \\ Guangzhou 510275, China \\ * Correspondence: fengqx8@mail.sysu.edu.cn
}

Received: 1 December 2018; Accepted: 5 January 2019; Published: 10 January 2019

\begin{abstract}
There have been many research studies that have examined the impact of financial development on economic growth, but few of them have explored this problem from the perspective of financial market information. In this paper, we investigate whether the stock price informativeness affect the listed firms' sustainable growth by using the Chinese manufacturing listed companies' data from 2007 to 2017. Specifically, we use the stock price nonsynchronicity and turnover rate to measure stock price informativeness, and the economic growth sustainability is proxied by the listed companies' total factor productivity, which is the driving force of firms' sustainable and steady growth. We find that higher stock price informativeness is associated with higher total factor productivity, no matter whether the stock price informativeness is proxied by the stock price nonsynchronicity or turnover rate. This finding is robust when we mitigate for endogeneity issues, and when we use the return on assets (ROA) as an alternative proxy for economic growth. Our results show that the stock price informativeness can significantly improve the total factor productivity of the listed companies, and play an important role in the sustainable development of listed manufacturing enterprises.
\end{abstract}

Keywords: stock price informativeness; stock price nonsynchronicity; turnover rate; total factor productivity; financial market information; sustainable development

\section{Introduction}

A large number of activities in the financial sector occur in the secondary financial markets, where various types of financial securities are traded between investors [1]. However, in such activities, funds and capital do not flow into the company. In most advanced economies, large amounts of money are used for secondary market transactions such as the stock market. Fama [2] believed that the stock price can reflect all of the relevant information in an efficient market, including the internal information of the managers and external investors' private information related to the state of the company. Will these trading activities and stock price informativeness affect the listed firms' total factor productivity (TFP), which is the core driving force for the sustainable and steady growth of the company? In this paper, from the perspective of stock price informativeness, we empirically studied the causal relationship between listed manufaturing firm's stock price informativness and TFP in China, exploring the actual effect of the Chinese stock market on manufacturing firms' sustainable dvelopment and growth. Specifically, we examine whether more informative stock prices are associated with higher TFP. 
Stock price informativeness may affect total factor productivity in two ways. First, stock price informativeness may influence TFP through managerial learning [3-5]. Stock prices include information that managers do not know, such as information about future investment and growth opportunities, future demand of the firm's products and services, and financing opportunities, which may be related to the total factor productivity [6]. Consequently, more information being included in stock prices will help the managers make investment decisions, as well as allocate resources and finance capital more efficiently. Second, stock price informativeness may affect productivity by strengthening corporate governance. More informative stock prices are associated with the better external and/or internal monitoring of managers, and thus mitigate the agency problem or alleviate the empire-building problem (i.e., investing non-profitable projects to create benefits for managers, or hiring more employees than required to run profitable projects). Hence, more informative stock prices may help the stockholder monitor the manager better [7], finally improving the TFP.

Our research question is important for several reasons. First, we choose to examine the impact of stock price informativeness on total factor productivity, which is the core driving force for the sustainable and steady development of firms, and is also one of the important factors determining firm growth and output (Solow [8]). Second, since the Chinese stock market has so far had only a very short history (since 1991), the institution and mechanism is still immature compared with the European and American stock markets, and the information efficiency in the Chinese stock market is very low, as pointed out by Morck et al. [9], and Jin and Myers [10]. As a result, whether the information of Chinese stocks promotes the TFP of listed companies is an important issue that remains unsolved. Our paper tries to answer this question. Third, our paper is helpful as it sheds light on the feedback effect from stock market prices to the real economy. A large number of activities in the financial sector occur in the secondary financial markets, where various types of financial securities are traded between investors. However, in such activities, funds and capital do not flow into the companies [1]. Our paper can give direct evidence on whether these activities can have effects on the real economy.

In this paper, we investigate whether managers use the information that is incorporated in stock prices to improve the firm's productivity, namely its total factor productivity. Specifically, we examine whether more informative stock prices are associated with higher firm TFP. To empirically test our hypothesis, we use the fixed effect method to estimate the level of the firm's total factor productivity, and use the estimated residual to proxy the TFP. The higher this residual, the higher the TFP. To measure the extent of stock price informativeness, hence the degree by which firm-specific information is incorporated into stock prices, we use two kinds of proxies: stock price nonsynchronicity and log turnover rate. The stock price nonsynchronicity, PSI, is a measure of stock price informativeness based on the $\mathrm{R}^{2}$ from asset pricing regressions, following Roll [11], Morck et al. [9], and Bennett et al. [12]. Following Chae [13], Ferreira and Laux [14], we use the log annual or quarterly turnover rate, which is derived from the CSMAR database directly, as the second measure of the stock price informativeness. In order to alleviate the endogeneity caused by the two-way casual relation, we use the average lagged stock price informativeness and turnover rate as our core independent variable in the econometric model. A higher value for the average lagged stock price nonsynchronicity and turnover rate indicates higher information incorporated in the stock prices, and hence higher stock price informativeness.

Using a sample of Chinese listed manufacturing firms over the period from 2007 to 2017, we show that a higher average lagged stock price nonsynchronicity or turnover rate (i.e., higher stock price informativeness) is significantly associated with higher firm productivity controlling other economic fundamentals. Actually, one unit of average lagged three years stock price nonsynchronicity (turnover rate) is associated with a 0.0914 (0.0653) unit increase in productivity. This finding not only happens when we use the annual data to estimate the econometric model, but also when we use the quarterly data to estimate the econometric model. This finding is consistent with the view that managers use the new information incorporated in stock prices (e.g., information about future investment, growth opportunities, and future financing policies) to improve the production process 
and technology, and hence the productivity. This result is also consistent with the idea that stock price infromativeness helps improve the monitoring mechanism of managers. Specifically, more informative stock prices result in a better monitoring of managers [7], which alleviates the agency problem, leading to more efficient productivity.

This finding remains robust when we address the endogeneity of stock price nonsynchronicity or turnover rate, using average lagged value (form previous one year to previous six years) as the independent variable to alleviate the two-way causal effects. Furthermore, we use the individual-time fixed-effect model to mitigate the omitted variable problem. In a robust test, when we use the return on assets (ROA) as an alternative proxy for firm's productivity, the quantitative relation still remains the same.

Our study mainly contributes to two strands of literature. First, by focusing on firm's productivity, which is crucial for firm's sustainable development, our paper extends the literature on how enterprise is affected by stock price informativeness through managerial learning and monitoring manager (Holmstrom and Tirole [15], Ferreira et al. [7]). The well-known study of Morck et al. [16] argued that "the explanatory power of relative stock returns for investment is unlikely to be evidence that the stock market provides new information to managers, since managers probably learn little from the market about their own firms' idiosyncratic prospects". Thus, the authors conclude that the stock market is somewhat of a side show. However, recent evidence suggests that stock prices influence firm's real activities. However, most of these studies focused on the investment efficiency, and our paper focuses on the firm's productivity outcome, which is important to the sustainable growth of the firm. For example, Chen et al. [17] argued that the stock market affects corporate investment decisions, because managers learn from the private information in stock prices about their own firms' fundamentals and show that the higher probability of informed trading leads (i.e., higher stock price informativeness) to higher investment sensitivity to stock prices (i.e., higher investment efficiency). Ben-Nasr and Alshwer [4] argued that not only the fixed investment efficiency will be affected by the stock price informativeness, but also the labor investment efficiency may be influenced by the information contained in the stock price through managerial learning and the monitoring manager. Essentially, the authors showed that a higher probability of informed trading (PIN) (i.e., higher stock price informativeness) is associated with higher labor investment efficiency. A one-standard deviation increase in PIN is associated with a $13.1 \%$ decrease in labor investment inefficiency.

Second, our study also contributes to the literature investigating what economic or financial factors will determine TFP. Our paper gives direct evidence that the informative stock price will increase a firm's TFP. Total factor productivity (TFP) is the core driving force for sustainable and steady economic growth. Since Solow [8] proposed this concept, many studies have examined the economic determinants of TFP. Wasserman et al. [18], Bertrand and Schoar [19], Bloom and Van [20], Bloom et al. [21] argued that managerial activities are an important cause of TFP differences. Denison [22], Jorgenson et al. [23], Hellerstein et al. [24], Abowd et al. [25], and Fox and Smeets [26] held the view that improvements in labor and capital quality can help increase TFP. Cohen and Levinthal [27], Aw et al. [28], and Doraszelski and Jaumandreu [29] pointed out that research and development $(R \& D)$ investment also plays an important role in the growth of total factor productivity.

At the same time, financial factors such as financial availability, financial development, corporate governance, and equity structure also play very important roles in the growth of TFP. However, few of these studies have studied the realationship between stock price informativeness and TFP. Gatti and Love [30], Butler, and Cornaggia [31] argued that higher financial availability is helpful for companies regarding expanding investment and production, thereby promoting the growth of TFP. Levin [32], Levine and Zervos [33], and Beck et al. [34] believed that financial development helps optimize the allocation of resources and promote technological innovation by diversifying investor risk and alleviating information asymmetry. In terms of corporate governance, Jones and Kato [35] compared the productivity of Japanese companies before and after the implementation of the employee stock ownership plans (ESOPs). Ittner et al. [36] held the view that the implementation of equity 
incentives for employees is helpful to attract and retain core employees, and therefore promote the technology upgrade of the company. Kim and Ouimet [37] analyzed the US corporate employee stock ownership plan, and believed that it has a positive impact on productivity through peer pressure, mutual supervision, and interest bundling. Regarding equity structure, Barth et al. [38] showed that family businesses have lower TFP than non-family businesses. Brav et al. [39] used the United States Census Bureau's factory-level data to study the long-term impact of hedge fund activity on firm productivity.

The paper is structured as follows. Section 2 contains the theoretical analysis and research hypothesis; Section 3 introduces the estimation method of total factor productivity and the measurement method of stock price informativeness; Section 4 introduces the source of data and related variables; Section 5 contains the econometric model design; Section 6 gives empirical results; Section 7 conducts robust tests; and Section 8 draws the conclusions.

\section{Theoretical Analysis and Hypothesis Development}

One of the basic functions of the stock market is to collect and deliver information through stock price changes. The stock price is generated by different traders in the market based on their own information, so the stock price contains the private information of these traders. Although these external traders do not have the internal information of the company, they are likely to have external information that the corporate managers do not know, such as product competitiveness, upstream and downstream industry developments, and the information of competitors. Corporate managers can use this external information contained in the stock price as a reference point for the company's investment decisions. This function is called the feedback effect of the stock market on the real economy.

The feedback effect of stock price informativeness can at least affect the TFP of listed companies through two channels. First, the managers can learn new private information from the stock prices, which helps to improve the efficiency of their decisions; second, the stock price informativeness also helps alleviate the agency problem, and improve internal and external monitor for managers.

A strand of literatures supports the managerial learning. The idea of managerial learning can be traced back to Hayek [40], who believes that stock prices contain useful information. Investors use their pieces of information to trade stocks, so the stock price aggegates all of this information. Not only managers, but other decision makers can also learn from this information to guide their decisions, which will consequently affects the firm's productivity or values. Fishman and Hagerty [41], Leland [42], Khanna et al. [43], and Bernhardt et al. [44] presented models where different types of speculators-insiders and outsiders-trade on their information. They argued that limiting insider trading reduces adverse selection, and thus encourages outsiders to trade on their information, which the managers do not possess. In these models, the decision makers or managers of enterprises will learn from the price, and this learning process will affect the real efficiency of firms. Dow and Gorton [45] studied a model where managers learn from prices. In the first equilibrium of the model, speculators can produce information and use it to trade stocks, so that their information is incorporated in prices. Managers then make investment decisions according to prices. In the other equilibrium, speculators do not produce information. Since there is no information in the prices, managers do not make investments. Boot and Thakor [46] and Subrahmanyam and Titman [47] argued that managers can learn from the stock price to rationalize a firm's choice to issue publicly-traded securities, rather than receiving private financing (e.g., from a bank). In these models, public trading allows the managers to infer information from its stock price and use it to improve its real decisions.

In recent years, most empirical studies have documented the effect of price information on firm investment, and use firms' investment outcomes to draw inferences on managerial learning from the stock market. Luo [3] reported evidence suggesting that mangers use information from the stock markets when finalizing mergers and acquisitions deals. Chen et al. [17] used United States (US) listed companies' stock price data to study how the private information of external investors affected the company's investment decisions. They find that the more information the stock price contains, 
the more efficient the company's investment becomes. Bakke and Whited [48] tested whether private information affects investment. This paper decomposed Tobin Q's variance into two components: a part considered to be related to investment by managers, and the other part not. The empirical results show that managers will learn the information in the stock price and use it to guide their investment decisions. The higher the private information content, the higher the investment-related component in Tobin's q. Foucault and Gehrig [49] and Foucault and Fresard [50] argued that cross-listing enhances managers' learning of stock prices, because it gives stock prices more information content. Foucault and Fresard [51] pointed out that managers not only learn information from their own stock price, but also from the stock price of "peer" enterprises. Given the above-mentioned arguments, stock price informativeness may affect firms' TFP, since it includes information that managers do not possess about the future demand of the firm's products and services, growth opportunities, and financing policies, which determine the level of the firms' productivity. Ozoguz and Rebello [52] also confirmed the positive relationship between investment and peers' valuation. They also found that this relationship is stronger when peers' valuation is more informative, and that it varies according to the firms' operating environment. Ben-Nasr and Alshwer [4] argued that not only the fixed investment efficiency will be affected by the stock price informativeness, but also the labor investment efficiency may be influenced by the information contained in the stock price through managerial learning and monitoring the manager. Essentially, the authors showed that a higher probability of informed trading (PIN) (i.e., higher stock price informativeness) is associated with higher labor investment efficiency. A one-standard deviation increase in PIN is associated with a $13.1 \%$ decrease in labor investment inefficiency. Zuo [53] examined whether managers learn from investors' private information in prices and incorporate this information in their earnings forecasts. The author used the extent of privately informed trading in the stock market as an empirical proxy for the amount of investors' private information in stock prices. He found that managers rely more strongly on stock returns when revising their earnings forecasts when the amount of investor information in the stock prices is higher.

The stock price informativeness not only impact firms' TFP thorough managerial learning, but also affects companies' productivity by strengthening corporate governance. Specifically, stock prices informativeness can discipline managers and enhance monitoring mechanisms. Informative stock prices may discipline managers, since they may be replaced if the takeover succeeds (Holmstrom and Tirole [15]). Ferreira et al. [7] believed that the information disclosed in stock prices allows supervision mechanisms to operate more effectively. For example, the company will become an easy-to-acquire target after a negative investment announcement as its stock price falls. Therefore, managers will try their best to avoid those negative investment behaviors. So, the more information the price contains, the more efficiently the board of director's members supervise the managers, since the board of director's members also learn new information from the stock market. Bennett et al. [54] believed that private information in stock prices could reduce the information gap between agents and principals, and improve the observability of the managerial working situation for stockholders.

Based on the analysis above, this paper proposes the following hypothesis.

Hypothesis 1. The stock price informativeness of Chinese listed companies can increase their total factor productivity.

\section{TFP and Stock Price Informativeness}

\subsection{Estimation of Total Factor Productivity of Listed Companies in China}

This section describes the estimation methodology of TFP that was used in this study. In recent years, with the emergence of more micro data from companies, more and more researchers have begun to use micro data to estimate TFP. However, the micro-level TFP estimation will encounter more endogenous problems. 
Suppose the Cobb Douglas function takes the following form:

$$
\mathrm{V}_{\mathrm{it}}=\mathrm{A}_{\mathrm{it}} \mathrm{L}_{\mathrm{it}}^{\beta_{1}} \mathrm{~K}_{\mathrm{it}}^{\beta_{\mathrm{k}}}
$$

$V_{i t}$ represents the new output of listed company i; $V_{i t}=Y_{i t}-M_{i t}$, where $Y_{i t}$ represents the total output of listed company $i$, and $M_{i t}$ represents the other intermediate factor input of listed company $i$ in the production process; $L_{i t}$ represents the labor input of listed company $i ; K_{i t}$ represents the capital investment of listed company $\mathrm{i}$; and $\mathrm{A}_{\mathrm{it}}$ represents the total factor productivity (TFP). By taking the logarithm of both sides of the equation, it can be converted into the following linear form:

$$
\mathrm{v}_{\mathrm{it}}=\alpha_{0}+\beta_{1} \mathrm{l}_{\mathrm{it}}+\beta_{\mathrm{k}} \mathrm{k}_{\mathrm{it}}+\mathrm{u}_{\mathrm{it}}
$$

Hence, the TFP estimate would be $\hat{\alpha}_{0}+\hat{u}_{i t}$, where the first term is common across the production units in the sample, and the second term is an idiosyncratic part to a particular producer. Estimating the TFP is usually divided into two steps. The first step is to estimate $\hat{\alpha}_{0}, \hat{\beta}_{1}$, and $\hat{\beta}_{\mathrm{k}}$; and the second step is to substitute the estimated values of $\hat{\alpha}_{0}, \hat{\beta}_{1}$, and $\hat{\beta}_{\mathrm{k}}$ into Equation (2), and then calculate the residual term for each period of each company. The residual obtained is the idiosyncratic part of TFP. Studies in the literature always take $\hat{\alpha}_{0}$ as the average technological level and use the residual term $\hat{\mathrm{u}}_{\mathrm{it}}$ (the idiosyncratic part) as the TFP for research (Schoar [55]; Giannetti et al. [56]). The calculation process of the second step is the same in different estimation methods, and the difference comes mainly from the first step, namely how to estimate the $\hat{\alpha}_{0}, \hat{\beta}_{1}$, and $\hat{\beta}_{\mathrm{k}}$.

Marshak and Andrews [57] pointed out that using the ordinary least squares method to estimate Equation (1) above would encounter the problem of simultaneous bias. They argued that when a company makes a decision about factor input, a part of the internal production efficiency shock can be observed, and this will make the factor input variable and the disturbance term related. So, there is an endogenous problem when we use OLS (ordinary least square regression) to estimate TFP, and its estimation results are likely to be biased.

Assuming productivity $\mathrm{u}_{\mathrm{it}}$ consists of two parts of productivity shocks, one is associated with labor and capital inputs, which can be observed by firms, and we call it $\omega_{i t}$. The other is $\varepsilon_{i t}$, which is the productivity shock that firms and econometricians cannot observe. For the sake of easy understanding, the above Formula (2) is rewritten as:

$$
\mathrm{v}_{\mathrm{it}}=\alpha_{0}+\beta_{1} \mathrm{l}_{\mathrm{it}}+\beta_{\mathrm{k}} \mathrm{k}_{\mathrm{it}}+\omega_{\mathrm{it}}+\varepsilon_{\mathrm{it}}
$$

where $\omega_{i t}$ represents the productivity shock associated with the labor $l_{i t}$ and the capital investment $\mathrm{k}_{\mathrm{it}}$ of the company $\mathrm{i}$, which can be observed at the period $\mathrm{t}$; and $\varepsilon_{\mathrm{it}}$ is defined as the unobservable productivity shock of the company $i$ at the period $t$. If OLS is used to estimate Equation (3) directly, since the labor input $l_{i t}$ and capital $k_{i t}$ of the company will be related to a productivity impact $\omega_{\text {it }}$ which can be observed, endogenous problems will be generated, resulting in biased estimated coefficients.

If $\omega_{i t}=\omega_{i t-1}$ is assumed, namely the productivity shocks that can be observed by the firm are fixed at each period, then using the fixed effect to estimate can avoid the endogeneity caused by the simultaneous bias problem mentioned above. Therefore, many researchers have introduced individual fixed effects and time fixed effects in Equation (3) to alleviate the endogeneity problems caused by simultaneous bias, as follows:

$$
\mathrm{v}_{\mathrm{it}}=\alpha_{0}+\beta_{\mathrm{l}} \mathrm{l}_{\mathrm{it}}+\beta_{\mathrm{k}} \mathrm{k}_{\mathrm{it}}+\mu_{\mathrm{i}}+\theta_{\mathrm{t}}+\tau_{\mathrm{it}}
$$

where $\mu_{\mathrm{i}}$ represents the individual fixed effect of the firm, and $\theta_{\mathrm{t}}$ represents the time fixed effect. Then, $\tau_{i t}$ represents the logarithmic form of TFP of the listed companies. After using fixed effect regression directly on the formula above, we can get $\hat{\tau}_{i t}$, which is considered to be the logarithmic form of the TFP of the listed company $i$ at period $t$. 


\subsection{Total Output, Labor, Capital, Intermediate Inputs, and Price Adjustment}

Two other important issues need to be addressed when estimating TFP. The first issue is the selection of specific indicators for total output, labor input, capital investment, and intermediate inputs. The second issue is the price adjustment of the indicators above. Due to the distinction in the data samples and function forms, there is a big difference in the processing of the above two problems in different studies.

Regarding the selection of indicators for total output, many literatures use the company's operating income or sales revenue, such as Tian and Twite [58], and Giantneti et al. [56]. However, since manufacturing companies tend to produce more products before they sell products, the indicator of sales revenue is likely to result in an underestimation of total output. So, we use the sum of the sales revenue and the inventory increment as a proxy for total output $y_{\text {it }}$ (Schoar, [55]), and then we use the gross domestic product (GDP) deflator to adjust the price of the total output.

In terms of the selection of indicators for capital investment, the mainstream literatures often adopt the company's net value of property plant and equipment as the proxy, such as Hsieh and Klenow [59], Kim and Ouimet [37], İmrohoroğlu and Tüzel [60], and Bennett et al. [12]. Then, we use the investment price index to adjust the capital input price following İmrohoroğlu and Tüzel [60] and Bennett et al. [12].

In this paper, we use the number of employees in listed companies as an indicator for labor input, following Levinsohn and Petrin [61], Ayyagari et al. [62], İmrohoroğlu and Tüzel [60], Giannetti et al. [56], and Fang et al. [63].

Regarding the selection of indicators for the intermediate factor inputs, this paper follows the method applied by Giannetti et al. [56]. The "Cash outflows for goods and services" from the cash flow statement and the increase in current accounts payable are used as proxies of intermediate factor inputs. Then, we use the GDP deflator to adjust the price, following İmrohoroğlu and Tüzel [60] and Bennett et al. [12].

\subsection{Stock Price Informativeness: The Stock Price Nonsynchronicity}

In the financial literature, the most important calculation method for stock price informativeness is using stock price nonsynchronicity (PSI). The stock price nonsynchronicity, PSI, is a measure of stock price informativeness based on the $\mathrm{R}^{2}$ from asset pricing regressions, following Roll [11], Morck et al. [9], and Bennett et al. [12]. We decompose the stock return into the systematic part explained by the market return and industry return, and a firm-specific residual variation. When there is relatively more firm-specific variation, the return moves less with the market return and the industry return, so that $\mathrm{R}^{2}$ is smaller. To perform our decomposition, we use the following linear regression:

$$
\mathrm{r}_{\mathrm{ijt}}=\alpha_{\mathrm{j} 0}+\alpha_{\mathrm{j} 1} \mathrm{r}_{\mathrm{mt}}+\alpha_{\mathrm{j} 2} \mathrm{r}_{\mathrm{ijt}}+\varepsilon_{\mathrm{ijt}}
$$

where $i$ is for firm $i, j$ is for industry $j$, and $t$ is for day $t, r_{i j t}$ is the stock return of firm $i$ in industry $j$ on day $t, r_{m t}$ is the value weighted market return on day $t$, and $r_{j t}$ is the value weighted industry return on day $t$. The weights are based on market capitalization.

The regression is estimated for each firm $j$ within a year, and the $R^{2}$ of the regression is used to construct $\mathrm{PSI}_{\mathrm{i}}$ for stock $\mathrm{i}$ in a given year as follows:

$$
\mathrm{PSI}_{\mathrm{i}}=\ln \left(\frac{1-\mathrm{R}_{\mathrm{i}}^{2}}{\mathrm{R}_{\mathrm{i}}^{2}}\right),
$$

In the above equation, PSI $_{i}$ is transformed to address the skewness and boundedness of $1-\mathrm{R}^{2}$ (Morck et al. [9]). The stock price is more informative when a stock becomes less correlated with the market and industry returns, i.e., when $\mathrm{R}^{2}$ falls, and hence $\mathrm{PSI}_{\mathrm{i}}$ increases. 


\subsection{Stock Price Informativeness: Turnover Rate}

The turnover rate is also used as a proxy of stock price informativeness by some of the studies in the literature. Blume, Easley, and O'Hara [64] established a theoretical model that analyzed the relationship between the volume of transaction, information, and price change, and showed how trading volume and price series provide information. Chae [13] explored how traders respond to private information by examining changes in trading volume before and after scheduled and unscheduled company announcements. The article pointed out that stock trading volume is inversely proportional to information asymmetry before the scheduled announcement, but becomes opposite after the announcement. The article also investigated the behavior of market makers and found that their price sensitivity increases through transactions before all announcements, which means they extract information from orders. Ferreira and Laux [14] considered the turnover rate to be another measure of stock price informativeness when studying the impact of corporate governance policies on stock price informativeness. Therefore, we use the tradable stock turnover rate as the second measure of stock price informativeness in this paper.

\section{Sample and Descriptive Statistics}

\subsection{Sample and Data Source}

The sample of this paper is the manufacturing listed company in China's A-share market from 2007 to 2017. The daily stock return and the daily stock market capitalization data are derived from the daily stock return file of the CSMAR financial database. The annual and quarterly data on accounts payable, property plant and equipment, inventory, cash, total assets, and total liabilities are derived from the balance sheet file of the CSMAR financial database. The annual and quarterly data on sales revenue and operating profit are derived from the profit statement file of the CSMAR financial database. The annual and quarterly cash flow paid for goods and services are derived from the cash flow statement file of the CSMAR financial database. The annual and quarterly data for the total number of employees is derived from the Wind database. The annual and quarterly data on the amount of $R \& D$ investment is derived from the CSMAR financial database. The annual and quarterly data of Tobin's q value are derived from the relative value index file of the CSMAR financial database. The annual and quarterly figures for the GDP deflator are from Oxford Economics, which are downloaded using DataStream under the codes CHXPGDP. and CHXPGDP.F. The annual and quarterly data for the investment price deflator are derived from Oxford Economics and downloaded using DataStream under the codes CHXPIFP. and CHXPIFP.F. More details can be seen in Appendix A.

\subsection{Meanings of Variable and Descriptive Statistics}

The variable symbols and meanings used in this article are described in the appendix. Tables 1 and 2 give a statistical description of the relevant variables.

Table 1. Statistical description (annual data). R\&D: research and development, ROA: return on assets.

\begin{tabular}{cccccc}
\hline Variables & $\mathbf{N}$ & Mean & sd & Min & Max \\
\hline tfp_fe & 18,659 & 0.000 & 1.015 & -9.416 & 4.659 \\
PSI & 24,818 & 0.342 & 1.018 & -12.240 & 10.590 \\
logYrTrdTurnR & 24,247 & 5.938 & 1.010 & -5.655 & 8.499 \\
TobinQA & 14,572 & 2.360 & 3.020 & 0.090 & 121.500 \\
logAsset & 14,572 & 21.950 & 1.290 & 16.960 & 28.510 \\
Cash/Asset & 14,572 & 0.180 & 0.130 & 0.000 & 0.850 \\
Debt/Asset & 14,572 & 0.460 & 0.790 & 0.010 & 63.970 \\
R\&D/Asset & 14,572 & 0.010 & 0.020 & 0.000 & 0.740 \\
ROA & 15,902 & 0.050 & 0.200 & -2.350 & 12.040 \\
\hline
\end{tabular}


Table 2. Statistical description (quarterly data).

\begin{tabular}{cccccc}
\hline Variables & $\mathbf{N}$ & Mean & sd & Min & Max \\
\hline tfp_fe & 68,973 & $2.31 \times 10^{-5}$ & 1.107 & -19.42 & 6.410 \\
PSI & 91,519 & 0.238 & 1.121 & -12.24 & 11.26 \\
logQtrFulTurnR & 50,552 & 4.390 & 0.813 & -4.625 & 6.967 \\
TobinQA & 43,406 & 2.275 & 2.560 & 0.0752 & 132.6 \\
logAsset & 43,406 & 21.89 & 1.267 & 16.62 & 28.52 \\
Cash/Asset & 43,406 & 0.172 & 0.128 & 0 & 0.883 \\
Debt/Asset & 43,406 & 0.453 & 0.555 & 0.00405 & 63.97 \\
R\&D/Asset & 43,406 & 0.00228 & 0.00924 & 0 & 0.277 \\
ROA & 50,552 & 0.0115 & 0.0638 & -1.000 & 6.714 \\
\hline
\end{tabular}

\section{Econometric Design}

Following Bennett et al. [12], our benchmark model was used to test the relationship between the stock price informativeness and TFP as follows:

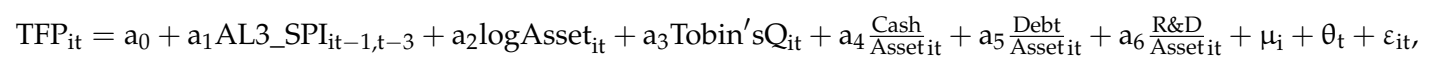

where $\mathrm{TFP}_{\text {it }}$ represents the total factor productivity of the listed companies. It is estimated by the fixed effect method. AL3_SPI $\mathrm{It}_{\mathrm{it}-1, \mathrm{t}-3}$ indicates that the average stock price informativeness of the listed company lagged for three years, i.e., $\mathrm{AL}_{-} \mathrm{SPI}_{\mathrm{it}-1, \mathrm{it}-3}=\frac{1}{3} \sum_{\mathrm{t}-1}^{\mathrm{t}-3} \mathrm{SPI}$, where the stock price informativeness is measured by the turnover rate and the stock price nonsynchronicity. In order to ensure the robustness of the conclusions, we will also give the average value of stock price informativeness of the previous year, two years, three years, four years, five years, and six years in the subsequent regression estimation. The reason why we take the average value of the previous stock price informativeness as our core independent variable of the regression is that it can help minimize the endogenous problem caused by the two-way causality. The core estimation coefficient we focus on is $a_{1}$, which indicates the impact of stock price informativeness on the total factor productivity of the listed companies. If the stock prices informativeness can promote the growth of the total factor productivity, then $\mathrm{a}_{1}$ should be significantly greater than zero.

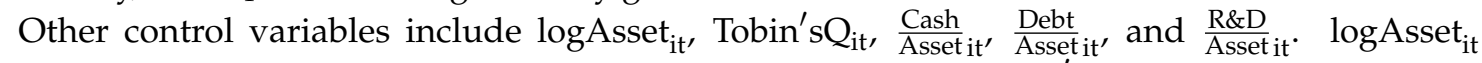
represents the natural logarithm of the listed company's total assets; Tobin's $Q_{i t}$ represents the value of the listed company's Tobin q, which is equal to the market value divided by the total assets; Cash indicates the ratio of cash to total assets in the listed company; $\frac{\text { Debt }}{\text { Asset it }}$ indicates the ratio of the total debt to the total assets of the listed company, in which the variable Debt uses the total liabilities; R\&D indicates the ratio of R\&D investment to the total assets of the listed companies, in which R\&D uses the total R\&D investment; and Asset indicates the total book value assets of the listed companies.

In addition, $\mu_{\mathrm{i}}$ represents the individual fixed effect of the listed company; $\theta_{\mathrm{t}}$ represents the year fixed effect; $\varepsilon_{i t}$ represents the disturbance term. The omitted variable problem is one of the sources of endogeneity. Since we use non-balanced panel data for regression, the fixed-effects method can help mitigate the endogenous problems caused by omitted variables.

\section{Empirical Results}

\subsection{Stock Price Nonsynchronicity and TFP}

Table 3 shows the annual data regression results estimated by model (7), where tfp_fe represents the TFP estimated by the individual and year fixed effects. AL1_PSI indicates the stock price nonsynchronicity for the previous year; AL2_PSI, AL3_PSI, AL4_PSI, AL5_PSI, and AL6_PSI indicate the average value of stock price nonsynchronicity for the previous two years, three years, four years, five years, and six years. Columns (1) to (6) represent the regression results of AL1_PSI to AL6_PSI, 
respectively. The $\mathrm{R}^{2}$ of each regression is $0.648,0.656,0.658,0.660,0.663$, and 0.661 respectively, indicating that our model can explain the variation of TFP to a large extent.

From the estimation result in column (1) in Table 3, we can see that the estimated coefficient of AL1_PSI is 0.0196 , and the $t$-statistic is 1.5961 , which is not significant at the $10 \%$ confidence level. The estimation result in column (2) shows that the estimated coefficient of AL2_PSI is 0.0511, and the value of the t-statistic is 2.7433 , which is significant at the $1 \%$ confidence level; the estimation result of column (3) displays that the estimated coefficient of AL3_PSI is 0.0914, and the t-statistic is 3.3149, which is significant at the $1 \%$ confidence level; the estimation result in column (4) presents that the estimated coefficient of AL4_PSI is 0.1536 , and the t-statistic is 4.2321, which is significant at the $1 \%$ confidence level; while the estimate of column (5) demonstrates that the estimated coefficient of AL5_PSI is 0.2082, and the $t$-statistic is 4.7067 , which is significant at the $1 \%$ confidence level. The estimation result of column (6) illustrates that the estimated coefficient of AL6_PSI is 0.2352 , and the t-statistic is 4.5140, which is significant at the $1 \%$ confidence level.

The above results show that except for AL1_PSI, all of the other estimated coefficients of the average stock price nonsynchronicity are significantly greater than 0 ; in addition, as the informativeness increases, the coefficient also shows a monotonous increasing trend. The quarterly data is also used to estimate the model, and the results are consistent with the annual data. The result is presented in Table 4. Our results show that the stock price informativeness can significantly improve the total factor productivity of listed companies and plays an important role in the sustainable development of the economy.

Table 3. Annual total factor productivity (TFP) and stock price nonsynchronicity.

\begin{tabular}{|c|c|c|c|c|c|c|}
\hline & (1) & (2) & (3) & (4) & (5) & (6) \\
\hline Variables & tfp_fe & tfp_fe & $t f p_{f} f e$ & $t f p_{-} f e$ & tfp_fe & tfp_fe \\
\hline AL1_PSI & $\begin{array}{c}0.0196 \\
(1.5961)\end{array}$ & & & & & \\
\hline AL2_PSI & & $\begin{array}{c}0.0511^{* * *} \\
(2.7433)\end{array}$ & & & & \\
\hline AL3_PSI & & & $\begin{array}{c}0.0914 * * * \\
(3.3149)\end{array}$ & & & \\
\hline AL4_PSI & & & & $\begin{array}{c}0.1536^{* * *} \\
(4.2321)\end{array}$ & & \\
\hline AL5_PSI & & & & & $\begin{array}{c}0.2082^{* * *} \\
(4.7067)\end{array}$ & \\
\hline AL6_PSI & & & & & & $\begin{array}{c}0.2352^{* * *} \\
(4.5140)\end{array}$ \\
\hline logAsset & $\begin{array}{l}0.3980^{* * *} \\
(12.4071)\end{array}$ & $\begin{array}{l}0.4238^{* * *} \\
(12.5363)\end{array}$ & $\begin{array}{l}0.4108^{* * *} \\
(11.0897)\end{array}$ & $\begin{array}{l}0.4120^{* * *} \\
(10.2993)\end{array}$ & $\begin{array}{c}0.3970 * * * \\
(9.1566)\end{array}$ & $\begin{array}{c}0.3992 * * * \\
(8.5600)\end{array}$ \\
\hline Tobin'sQ & $\begin{array}{c}0.0396^{* * * *} \\
(3.7411)\end{array}$ & $\begin{array}{c}0.0420^{* * *} \\
(5.3331)\end{array}$ & $\begin{array}{c}0.0454^{* * *} \\
(5.6415)\end{array}$ & $\begin{array}{c}0.0422 * * * \\
(4.2526)\end{array}$ & $\begin{array}{c}0.0351^{* * *} \\
(3.1899)\end{array}$ & $\begin{array}{c}0.0318^{* * *} \\
(2.8845)\end{array}$ \\
\hline Cash/Asset & $\begin{array}{c}0.5164^{* * *} \\
(5.5693)\end{array}$ & $\begin{array}{c}0.5534^{* * *} \\
(4.8253)\end{array}$ & $\begin{array}{c}0.6168^{* * *} \\
(4.5825)\end{array}$ & $\begin{array}{c}0.6884^{* * *} \\
(4.5602)\end{array}$ & $\begin{array}{c}0.7301^{* * *} \\
(4.2630)\end{array}$ & $\begin{array}{c}0.7717^{* * *} \\
(4.1105)\end{array}$ \\
\hline Debt/Asset & $\begin{array}{l}-0.0187^{* *} \\
(-2.1224)\end{array}$ & $\begin{array}{l}-0.0204^{* *} \\
(-2.5634)\end{array}$ & $\begin{array}{c}-0.0245^{* * *} \\
(-2.6912)\end{array}$ & $\begin{array}{c}-0.0235^{* * *} \\
(-2.6423)\end{array}$ & $\begin{array}{c}-0.0237^{* * *} \\
(-2.6763)\end{array}$ & $\begin{array}{l}-0.0224 \text { ** } \\
(-2.2624)\end{array}$ \\
\hline R\&D/Asset & $\begin{array}{c}0.7713 \\
(1.3071)\end{array}$ & $\begin{array}{c}1.1637 \\
(1.5543)\end{array}$ & $\begin{array}{c}0.9740 \\
(1.3313)\end{array}$ & $\begin{array}{c}0.7374 \\
(1.0492)\end{array}$ & $\begin{array}{c}0.4914 \\
(0.7068)\end{array}$ & $\begin{array}{c}0.6671 \\
(0.6899)\end{array}$ \\
\hline Intercept term & $\begin{array}{l}-8.6739 * * * \\
(-12.3826)\end{array}$ & $\begin{array}{l}-9.2414^{* * *} \\
(-12.5857)\end{array}$ & $\begin{array}{l}-9.0017^{* * *} \\
(-11.1603)\end{array}$ & $\begin{array}{l}-9.0471 * * * \\
(-10.3264)\end{array}$ & $\begin{array}{c}-8.6886^{* * *} \\
(-9.1337)\end{array}$ & $\begin{array}{c}-8.7373^{* * * *} \\
(-8.5254)\end{array}$ \\
\hline Sample size & 14,572 & 12,922 & 11,557 & 10,385 & 9318 & 8288 \\
\hline$R^{2}$ & 0.648 & 0.656 & 0.658 & 0.660 & 0.663 & 0.661 \\
\hline Adjusted $\mathrm{R}^{2}$ & 0.582 & 0.589 & 0.591 & 0.591 & 0.589 & 0.586 \\
\hline
\end{tabular}

All of the models control the individual and year fixed effects; ${ }^{* * *}, * *$, and ${ }^{*}$ indicate statistical significance at $1 \%, 5 \%$, and $10 \%$ respectively; the robust $\mathrm{t}$-statistic adjusted for clustering by firm is indicated inside the parentheses. 
Table 4. Quarterly TFP and stock price nonsynchronicity.

\begin{tabular}{|c|c|c|c|c|c|c|}
\hline & (1) & (2) & (3) & (4) & (5) & (6) \\
\hline Variables & tfp_fe_ols & tfp_fe_ols & tfp_fe_ols & tfp_fe_ols & tfp_fe_ols & tfp_fe_ols \\
\hline AL1_PSI & $\begin{array}{c}-0.0008 \\
(-0.0578)\end{array}$ & & & & & \\
\hline AL2_PSI & & $\begin{array}{c}0.0210 \\
(0.9734)\end{array}$ & & & & \\
\hline AL3_PSI & & & $\begin{array}{c}0.0831 * * * \\
(2.7962)\end{array}$ & & & \\
\hline AL4_PSI & & & & $\begin{array}{c}0.1523^{* * *} \\
(4.0311)\end{array}$ & & \\
\hline AL5_PSI & & & & & $\begin{array}{c}0.1810 * * * \\
(4.0951)\end{array}$ & \\
\hline AL6_PSI & & & & & & $\begin{array}{c}0.2096^{* * *} \\
(3.8872)\end{array}$ \\
\hline logAsset & $\begin{array}{l}0.4380^{* * *} \\
(14.0613)\end{array}$ & $\begin{array}{l}0.4552 * * * \\
(12.9052)\end{array}$ & $\begin{array}{l}0.4591 * * * \\
(11.8983)\end{array}$ & $\begin{array}{l}0.4534^{* * *} \\
(10.9992)\end{array}$ & $\begin{array}{l}0.4403^{* * *} \\
(10.5261)\end{array}$ & $\begin{array}{c}0.4071^{* * *} \\
(9.5500)\end{array}$ \\
\hline Tobin'sQ & $\begin{array}{c}0.0401^{* * *} \\
(4.3135)\end{array}$ & $\begin{array}{c}0.0522 * * * \\
(5.3471)\end{array}$ & $\begin{array}{c}0.0576^{* * *} \\
(7.1019)\end{array}$ & $\begin{array}{c}0.0614^{* * *} \\
(6.4259)\end{array}$ & $\begin{array}{c}0.0568^{* * *} \\
(5.7526)\end{array}$ & $\begin{array}{c}0.0548^{* * *} \\
(5.3645)\end{array}$ \\
\hline Cash/Asset & $\begin{array}{c}0.4274^{* * *} \\
(5.7085)\end{array}$ & $\begin{array}{c}0.4198^{* * *} \\
(4.7551)\end{array}$ & $\begin{array}{c}0.3754^{* * *} \\
(3.6352)\end{array}$ & $\begin{array}{c}0.4006^{* * *} \\
(3.4880)\end{array}$ & $\begin{array}{c}0.4801 * * * \\
(3.7862)\end{array}$ & $\begin{array}{c}0.4489^{* * *} \\
(3.2481)\end{array}$ \\
\hline Debt/Asset & $\begin{array}{l}-0.0330 \\
(-2.1587)\end{array}$ & $\begin{array}{c}-0.0504^{* * *} \\
(-3.3082)\end{array}$ & $\begin{array}{l}-0.1615^{*} \\
(-1.7928)\end{array}$ & $\begin{array}{c}-0.1438 \\
(-1.5317)\end{array}$ & $\begin{array}{l}-0.1827^{*} \\
(-1.7763)\end{array}$ & $\begin{array}{c}-0.1634 \\
(-1.3349)\end{array}$ \\
\hline R\&D/Asset & $\begin{array}{l}-2.1089 * * \\
(-2.1243)\end{array}$ & $\begin{array}{l}-1.2258 \\
(-1.1327)\end{array}$ & $\begin{array}{l}-0.4190 \\
(-0.3245)\end{array}$ & $\begin{array}{l}-0.5289 \\
(-0.3957)\end{array}$ & $\begin{array}{l}-1.9409 \\
(-1.3710)\end{array}$ & $\begin{array}{l}-2.2849 \\
(-1.0981)\end{array}$ \\
\hline Intercept term & $\begin{array}{l}-8.6037^{* * *} \\
(-12.6735)\end{array}$ & $\begin{array}{l}-9.0107^{* * *} \\
(-11.7022)\end{array}$ & $\begin{array}{l}-9.0745^{* * *} \\
(-10.7748)\end{array}$ & $\begin{array}{l}-9.7075^{* * *} \\
(-10.8766)\end{array}$ & $\begin{array}{l}-9.3909^{* * *} \\
(-10.4145)\end{array}$ & $\begin{array}{c}-8.7956^{* * *} \\
(-9.4242)\end{array}$ \\
\hline Sample size & 43,646 & 37,274 & 32,255 & 27,957 & 24,244 & 20,008 \\
\hline$R^{2}$ & 0.465 & 0.481 & 0.491 & 0.498 & 0.503 & 0.503 \\
\hline Adjusted $\mathrm{R}^{2}$ & 0.437 & 0.452 & 0.460 & 0.466 & 0.470 & 0.470 \\
\hline
\end{tabular}

All of the models control the individual and year-quarter fixed effects; ${ }^{* * *},{ }^{* *}$, and ${ }^{*}$ indicate statistical significance at $1 \%, 5 \%$, and $10 \%$ respectively; the robust $t$-statistic adjusted for clustering by firm is indicated inside the parentheses.

\subsection{Turnover Rate and TFP}

Table 5 shows the annual data regression results estimated by model (7), where AL1_logYrTrdTurnR indicates the yearly tradable stock turnover rate of the previous year. Meanwhile, AL2_ logYrTrdTurnR, AL3_ logYrTrdTurnR, AL4_ logYrTrdTurnR, AL5_ logYrTrdTurnR, and AL6_ logYrTrdTurnR indicate the the average value of turnover rate for the previous two years, three years, four years, five years, and six years. Columns (1) to (6) represent the regression results of AL1_ logYrTrdTurnR to AL6_ $\log Y r T r d T u r n R$, respectively. The $\mathrm{R}^{2}$ of each regression are all more than 0.6 , indicating that our model can explain to a large extent the variation of TFP.

The estimation result of column (1) in Table 5 shows that the estimated coefficient of AL1_logYrTrdTurnR is 0.0074, and the estimation result of column (2) shows that the estimated coefficient of AL2_logYrTrdTurnR is 0.0322 , both of which are not significant at the $10 \%$ confidence level. However, the estimated coefficient of AL3_logYrTrdTurnR is 0.0653, the t-statistic is 2.2889, which is significant at the 5\% confidence level. The estimated coefficient of AL4_logYrTrdTurnR, AL5_logYrTrdTurnR, and AL6_logYrTrdTurnR are 0.1198, 0.1435, and 0.1853, respectively, which are all significant at the $1 \%$ confidence level.

Except for AL1_logYrTrdTurnR and AL2_logYrTrdTurnR, the coefficients of stock price informativeness are all significantly positive. Similar to the regression result using stock price nonsynchronicity as the proxy of the stock price informativeness, the positive coefficient also shows a monotonous increasing trend as the stock price informativeness increases. The quarterly turnover rate data is also used to estimate model (7), and the results are consistent with the annual data, which is shown in Table 6. 
Table 5. Annual TFP and turnover rate.

\begin{tabular}{|c|c|c|c|c|c|c|}
\hline & (1) & (2) & (3) & (4) & (5) & (6) \\
\hline Variables & tfp_fe & tfp_fe & tfp_fe & $t f p_{-} f e$ & tfp_fe & tfp_fe \\
\hline AL1_logYrTrdTurnR & $\begin{array}{c}0.0074 \\
(0.6718)\end{array}$ & & & & & \\
\hline AL2_logYrTrdTurnR & & $\begin{array}{c}0.0322 \\
(1.5415)\end{array}$ & & & & \\
\hline AL3_logYrTrdTurnR & & & $\begin{array}{c}0.0653 * * \\
(2.2889)\end{array}$ & & & \\
\hline AL4_logYrTrdTurnR & & & & $\begin{array}{c}0.1198^{* * *} \\
(3.1233)\end{array}$ & & \\
\hline AL5_logYrTrdTurnR & & & & & $\begin{array}{c}0.1435^{* * *} \\
(2.8685)\end{array}$ & \\
\hline AL6_logYrTrdTurnR & & & & & & $\begin{array}{c}0.1853^{* * *} \\
(3.1048)\end{array}$ \\
\hline $\log$ Asset & $\begin{array}{l}0.3989^{* * *} \\
(12.3432)\end{array}$ & $\begin{array}{l}0.4170^{* * *} \\
(12.1574)\end{array}$ & $\begin{array}{l}0.4028^{* * *} \\
(10.8083)\end{array}$ & $\begin{array}{l}0.4075^{* * *} \\
(10.0408)\end{array}$ & $\begin{array}{c}0.3907^{* * *} \\
(8.8345)\end{array}$ & $\begin{array}{c}0.3939^{* * *} \\
(8.2766)\end{array}$ \\
\hline Tobin'sQ & $\begin{array}{c}0.0413 \text { *** } \\
(3.9755)\end{array}$ & $\begin{array}{c}0.0407^{* * * *} \\
(4.6170)\end{array}$ & $\begin{array}{c}0.0433^{* * * *} \\
(5.2699)\end{array}$ & $\begin{array}{c}0.0457 * * * \\
(4.6089)\end{array}$ & $\begin{array}{c}0.0398^{* * *} \\
(3.4589)\end{array}$ & $\begin{array}{c}0.0363^{* * *} \\
(3.1537)\end{array}$ \\
\hline Cash/Asset & $\begin{array}{c}0.5479 * * * \\
(5.9848)\end{array}$ & $\begin{array}{c}0.5827^{* * * *} \\
(5.0801)\end{array}$ & $\begin{array}{c}0.6510^{* * * *} \\
(4.8259)\end{array}$ & $\begin{array}{c}0.7408^{* * *} \\
(4.8869)\end{array}$ & $\begin{array}{c}0.8008^{* * *} \\
(4.6361)\end{array}$ & $\begin{array}{c}0.8437 * * * \\
(4.4635)\end{array}$ \\
\hline Debt/Asset & $\begin{array}{c}-0.0188^{* * *} \\
(-3.1965)\end{array}$ & $\begin{array}{c}-0.0176^{* * *} \\
(-3.4205)\end{array}$ & $\begin{array}{c}-0.0196^{* * *} \\
(-3.6091)\end{array}$ & $\begin{array}{c}-0.0208^{* * *} \\
(-3.4411)\end{array}$ & $\begin{array}{c}-0.0219^{* * *} \\
(-3.5463)\end{array}$ & $\begin{array}{c}-0.0213^{* * *} \\
(-3.0061)\end{array}$ \\
\hline R\&D/Asset & $\begin{array}{c}0.7843 \\
(1.3405)\end{array}$ & $\begin{array}{c}1.1602 \\
(1.5516)\end{array}$ & $\begin{array}{c}0.9842 \\
(1.3384)\end{array}$ & $\begin{array}{c}0.6902 \\
(1.0037)\end{array}$ & $\begin{array}{c}0.6245 \\
(0.8832)\end{array}$ & $\begin{array}{c}0.8113 \\
(0.8283)\end{array}$ \\
\hline Intercept term & $\begin{array}{l}-8.7351^{* * *} \\
(-12.1016)\end{array}$ & $\begin{array}{l}-9.2728^{* * *} \\
(-12.0149)\end{array}$ & $\begin{array}{l}-9.1877^{* * *} \\
(-10.8752)\end{array}$ & $\begin{array}{l}-9.6090 * * * \\
(-10.3088)\end{array}$ & $\begin{array}{c}-9.3526^{* * *} \\
(-9.1413)\end{array}$ & $\begin{array}{c}-9.6549 * * * \\
(-8.7422)\end{array}$ \\
\hline Sample size & 14,597 & 12,945 & 11,580 & 10,411 & 9346 & 8324 \\
\hline$R^{2}$ & 0.647 & 0.656 & 0.657 & 0.658 & 0.661 & 0.659 \\
\hline Adjusted $R^{2}$ & 0.582 & 0.588 & 0.590 & 0.588 & 0.586 & 0.584 \\
\hline
\end{tabular}

All of the models control the individual and year fixed effects; ${ }^{* * * * *}$, and ${ }^{*}$ indicate statistical significance at $1 \%, 5 \%$, and $10 \%$ respectively; the robust t-statistic adjusted for clustering by firm is indicated inside the parentheses.

Table 6. Quarterly TFP and turnover rate.

\begin{tabular}{|c|c|c|c|c|c|c|}
\hline & (1) & (2) & (3) & (4) & (5) & (6) \\
\hline Variables & tfp_fe_ols & tfp_fe_ols & tfp_fe_ols & tfp_fe_ols & tfp_fe_ols & tfp_fe_ols \\
\hline AL1_logQrTrdTurnR & $\begin{array}{c}-0.0068 \\
(-0.5406)\end{array}$ & & & & & \\
\hline AL2_logQrTrdTurnR & & $\begin{array}{c}0.0108 \\
(0.5734)\end{array}$ & & & & \\
\hline AL3_logQrTrdTurnR & & & $\begin{array}{l}0.0484 * \\
(1.8494)\end{array}$ & & & \\
\hline AL4_logQrTrdTurnR & & & & $\begin{array}{l}0.1019 * * * \\
(2.8151)\end{array}$ & & \\
\hline AL5_logQrTrdTurnR & & & & & $\begin{array}{c}0.1384^{* * *} \\
(3.0327)\end{array}$ & \\
\hline AL6_logQrTrdTurnR & & & & & & $\begin{array}{l}0.1393 * * \\
(2.2741)\end{array}$ \\
\hline logAsset & $\begin{array}{l}0.4416^{* * *} \\
(14.1072)\end{array}$ & $\begin{array}{l}0.4548^{* * *} \\
(12.4539)\end{array}$ & $\begin{array}{l}0.4660^{* * *} \\
(11.9497)\end{array}$ & $\begin{array}{l}0.4653^{* * *} \\
(11.0652)\end{array}$ & $\begin{array}{l}0.4496^{* * *} \\
(10.6303)\end{array}$ & $\begin{array}{c}0.4087^{* * * *} \\
(9.4397)\end{array}$ \\
\hline Tobin'sQ & $\begin{array}{c}0.0399 * * * \\
(4.1951)\end{array}$ & $\begin{array}{c}0.0487^{* * * *} \\
(4.1848)\end{array}$ & $\begin{array}{c}0.0617^{* * * *} \\
(7.6650)\end{array}$ & $\begin{array}{c}0.0672^{* * *} \\
(7.1192)\end{array}$ & $\begin{array}{c}0.0616^{* * * *} \\
(6.2875)\end{array}$ & $\begin{array}{c}0.0619^{* * *} \\
(6.1191)\end{array}$ \\
\hline Cash/Asset & $\begin{array}{c}0.4334^{* * *} \\
(5.7275)\end{array}$ & $\begin{array}{c}0.4179^{* * *} \\
(4.6979)\end{array}$ & $\begin{array}{c}0.3928^{* * * *} \\
(3.8139)\end{array}$ & $\begin{array}{c}0.4457^{* * *} \\
(3.8919)\end{array}$ & $\begin{array}{c}0.5409^{* * *} \\
(4.2815)\end{array}$ & $\begin{array}{c}0.5001^{* * *} \\
(3.6185)\end{array}$ \\
\hline Debt/Asset & $\begin{array}{l}-0.0334^{* *} \\
(-2.1888)\end{array}$ & $\begin{array}{l}-0.0447^{* *} \\
(-2.4391)\end{array}$ & $\begin{array}{l}-0.1435 \\
(-1.5883)\end{array}$ & $\begin{array}{c}-0.1276 \\
(-1.3137)\end{array}$ & $\begin{array}{l}-0.1665 \\
(-1.6252)\end{array}$ & $\begin{array}{c}-0.1173 \\
(-0.9723)\end{array}$ \\
\hline R\&D/Asset & $\begin{array}{l}-2.1156^{* *} \\
(-2.1499)\end{array}$ & $\begin{array}{l}-1.2542 \\
(-1.1650)\end{array}$ & $\begin{array}{l}-0.5970 \\
(-0.4627)\end{array}$ & $\begin{array}{l}-0.5460 \\
(-0.4115)\end{array}$ & $\begin{array}{l}-1.6175 \\
(-1.1404)\end{array}$ & $\begin{array}{l}-2.2365 \\
(-1.1002)\end{array}$ \\
\hline Intercept term & $\begin{array}{l}-8.6539 * * * \\
(-12.5557)\end{array}$ & $\begin{array}{l}-9.0242^{* * *} \\
(-11.2254)\end{array}$ & $\begin{array}{l}-9.3888^{* * *} \\
(-10.9595)\end{array}$ & $\begin{array}{c}-10.3684^{* * *} \\
(-11.1991)\end{array}$ & $\begin{array}{c}-10.1476^{* * *} \\
(-10.7954)\end{array}$ & $\begin{array}{c}-9.4732^{* * *} \\
(-9.6194)\end{array}$ \\
\hline Sample size & 43,767 & 37,436 & 32,436 & 28,157 & 24,457 & 20,194 \\
\hline $\mathrm{R}^{2}$ & 0.466 & 0.481 & 0.491 & 0.497 & 0.503 & 0.505 \\
\hline Adjusted $\mathrm{R}^{2}$ & 0.438 & 0.452 & 0.460 & 0.465 & 0.470 & 0.472 \\
\hline
\end{tabular}

All of the models control the individual and year-quarter fixed effects; $* * * * *$, and ${ }^{*}$ indicate statistical significance at $1 \%$, $5 \%$, and $10 \%$ respectively; the robust $t$-statistic adjusted for clustering by firm is indicated inside the parentheses. 


\subsection{Discussion}

The results above show that the informative stock price has a positive effect on the listed manufacturing firms' total factor productivity in China. Specifically, the higher average lagged stock price nonsynchronicity or turnover rate (i.e., higher stock price informativeness) is significantly associated with higher firm-level productivity when controlling for other economic fundamentals, no matter the annual or quarterly regression.

Our findings are consistent with the view that managers can learn new information through stock prices, and use this new information to guide real decisions, leading to the better allocation of resources and higher firm-level productivity. For example, Chen et al. [17] believed that investment Tobin q sensitivity is a good proxy for investment efficiency. They argue that managers can learn new information and improve their investment decisions. Their finding suggests that when the stock price informativeness rises, the investment-Tobin q sensitivity will also go up. Our finding is in conformity with their view, but we directly study how stock price informativeness affects firm-level total factor productivity. The result in our paper is also consistent with the findings of Bennett et al. [12], which also studied the relation between stock price informativeness and firm-level productivity. However, they use the data of the US stock market, which is the most advanced market in the world, and quite different from the Chinese stock market.

Furthermore, our findings are consistent with the view that stock price informativeness can help improve monitoring managers. Ferreira et al. [7] believed that members of the board of directors also learn new information from the stock market. When the price contains more information, the board of director's members will supervise managers more efficiently. Bennett et al. [54] suggested that private information in stock prices could improve the observability of the managerial working situation for stockholders. Our findings do not study how the stock price informativeness influences the corporate governance, but directly extend these literatures by investigating the outcome of the corporate governance.

\section{Other Robustness Test}

In order to ensure the robustness of our results, the ROA is used as the second measure of the productivity of listed companies. Table 7 shows the regression results of model (7) using the annual ROA data. ROA represents the return on total assets of a listed company, which is equal to the operating profit at the end of the year divided by the total assets at the beginning of the year. AL2_PSI, AL3_PSI, AL4_PSI, AL5_PSI, and AL6_PSI indicate the average value of stock price nonsynchronicity the previous two years, three years, four years, five years, and six years respectively. Columns (1) to (6) represent the regression results of AL1_PSI to AL6_PSI, respectively.

From Table 7, we can observe that estimated coefficients from AL1_PSI to AL6_PSI are 0.0225, $0.0388,0.0332,0.0400,0.0478$, and 0.0505 respectively. All of these estimated coefficients are significant at the $1 \%$ confidence level. In addition, the quarterly data is also used to estimate the relationship between stock price nonsynchronicity and ROA, which is basically consistent with the annual data, as shown in Table 8.

Our robust check shows that the stock price informativeness can significantly improve the total factor productivity of the listed companies, and plays an important role in the sustainable development of the company and economy. 
Table 7. ROA and stock price nonsynchronicity.

\begin{tabular}{|c|c|c|c|c|c|c|}
\hline & (1) & (2) & (3) & (4) & (5) & (6) \\
\hline Variables & ROA & ROA & ROA & ROA & ROA & ROA \\
\hline AL1_PSI & $\begin{array}{c}0.0225^{* * * *} \\
(2.9301)\end{array}$ & & & & & \\
\hline AL2_PSI & & $\begin{array}{c}0.0388^{* * * *} \\
(2.6171)\end{array}$ & & & & \\
\hline AL3_PSI & & & $\begin{array}{c}0.0332 * * * \\
(4.6253)\end{array}$ & & & \\
\hline AL4_PSI & & & & $\begin{array}{c}0.0400^{* * *} \\
(3.7950)\end{array}$ & & \\
\hline AL5_PSI & & & & & $\begin{array}{c}0.0478^{* * *} \\
(3.2498)\end{array}$ & \\
\hline AL6_PSI & & & & & & $\begin{array}{c}0.0505^{* * *} \\
(3.2602)\end{array}$ \\
\hline logAsset & $\begin{array}{c}0.1240 * * * \\
(4.5979)\end{array}$ & $\begin{array}{c}0.1413^{* * * *} \\
(4.4930)\end{array}$ & $\begin{array}{c}0.1453^{* * *} \\
(4.1081)\end{array}$ & $\begin{array}{c}0.1532 * * * \\
(3.9362)\end{array}$ & $\begin{array}{c}0.1599 * * * \\
(3.7667)\end{array}$ & $\begin{array}{c}0.1648 * * * \\
(3.5858)\end{array}$ \\
\hline Tobin'sQ & $\begin{array}{c}0.0040 \\
(0.7745)\end{array}$ & $\begin{array}{c}0.0106^{* * * *} \\
(2.7119)\end{array}$ & $\begin{array}{c}0.0096^{* * *} \\
(2.5795)\end{array}$ & $\begin{array}{c}0.0097 * * \\
(2.2595)\end{array}$ & $\begin{array}{c}0.0088 * * \\
(1.9673)\end{array}$ & $\begin{array}{c}0.0089 \\
(1.5048)\end{array}$ \\
\hline Cash/Asset & $\begin{array}{l}0.0723^{*} \\
(1.8795)\end{array}$ & $\begin{array}{c}0.0518 \\
(0.9198)\end{array}$ & $\begin{array}{l}0.1021 * * \\
(2.0555)\end{array}$ & $\begin{array}{c}0.0904 \\
(1.5657)\end{array}$ & $\begin{array}{c}0.0823 \\
(1.2361)\end{array}$ & $\begin{array}{c}0.0737 \\
(1.0125)\end{array}$ \\
\hline Debt/Asset & $\begin{array}{l}-0.0484 * \\
(-1.8684)\end{array}$ & $\begin{array}{l}-0.0553 * \\
(-1.9414)\end{array}$ & $\begin{array}{l}-0.0189^{*} \\
(-1.7349)\end{array}$ & $\begin{array}{l}-0.0181^{*} \\
(-1.6957)\end{array}$ & $\begin{array}{c}-0.0178 \\
(-1.6399)\end{array}$ & $\begin{array}{l}-0.0190 * \\
(-1.6680)\end{array}$ \\
\hline R\&D/Asset & $\begin{array}{c}0.2714 \\
(1.2627)\end{array}$ & $\begin{array}{c}0.3134 \\
(1.1828)\end{array}$ & $\begin{array}{c}0.3031 \\
(1.1021)\end{array}$ & $\begin{array}{c}0.2841 \\
(0.9859)\end{array}$ & $\begin{array}{c}0.2735 \\
(0.9182)\end{array}$ & $\begin{array}{c}0.3613 \\
(0.9034)\end{array}$ \\
\hline Intercept term & $\begin{array}{c}-2.5852^{* * *} \\
(-4.4933)\end{array}$ & $\begin{array}{c}-2.9813^{* * *} \\
(-4.4215)\end{array}$ & $\begin{array}{c}-3.0921 * * * \\
(-4.0870)\end{array}$ & $\begin{array}{c}-3.2742 * * * \\
(-3.9236)\end{array}$ & $\begin{array}{c}-3.4196^{* * * *} \\
(-3.7484)\end{array}$ & $\begin{array}{c}-3.5324^{* * *} \\
(-3.5673)\end{array}$ \\
\hline Sample size & 15,911 & 14,155 & 12,708 & 11,450 & 10,316 & 9220 \\
\hline $\mathrm{R}^{2}$ & 0.208 & 0.227 & 0.259 & 0.264 & 0.260 & 0.274 \\
\hline Adjusted $\mathrm{R}^{2}$ & 0.0705 & 0.0869 & 0.123 & 0.125 & 0.110 & 0.125 \\
\hline
\end{tabular}

All of the models control the individual and year fixed effects; ***, **, and * indicate statistical significance at 1\%, $5 \%$, and $10 \%$ respectively; the robust $\mathrm{t}$-statistic adjusted for clustering by firm is indicated inside the parentheses.

Table 8. Quarterly-ROA and stock price nonsynchronicity.

\begin{tabular}{|c|c|c|c|c|c|c|}
\hline & (1) & (2) & (3) & (4) & (5) & (6) \\
\hline VARIABLES & ROA & ROA & ROA & ROA & ROA & ROA \\
\hline AL1_spi_r2 & $\begin{array}{c}0.0067^{* * *} \\
(4.2568)\end{array}$ & & & & & \\
\hline AL2_spi_r2 & & $\begin{array}{c}0.0073^{* * *} \\
(5.5120)\end{array}$ & & & & \\
\hline AL3_spi_r2 & & & $\begin{array}{c}0.0109 \text { *** } \\
(6.3129)\end{array}$ & & & \\
\hline AL4_spi_r2 & & & & $\begin{array}{c}0.0155^{* * *} \\
(5.7589)\end{array}$ & & \\
\hline AL5_spi_r2 & & & & & $\begin{array}{c}0.0175^{* * *} \\
(5.1376)\end{array}$ & \\
\hline AL6_spi_r2 & & & & & & $\begin{array}{c}0.0154^{* * *} \\
(4.7343)\end{array}$ \\
\hline $\log$ Asset & $\begin{array}{c}0.0212 * * * \\
(4.4700)\end{array}$ & $\begin{array}{c}0.0226^{* * *} \\
(3.7505)\end{array}$ & $\begin{array}{c}0.0275^{* * *} \\
(3.9710)\end{array}$ & $\begin{array}{c}0.0288^{* * *} \\
(3.8574)\end{array}$ & $\begin{array}{c}0.0260^{* * *} \\
(3.3824)\end{array}$ & $\begin{array}{c}0.0265^{* * *} \\
(2.8400)\end{array}$ \\
\hline TobinQA & $\begin{array}{c}0.0007^{* * *} \\
(2.5210)\end{array}$ & $\begin{array}{c}0.0012 * * * \\
(2.7800)\end{array}$ & $\begin{array}{c}0.0022^{* * *} \\
(5.6371)\end{array}$ & $\begin{array}{c}0.0020 * * * \\
(4.7320)\end{array}$ & $\begin{array}{c}0.0018^{* * *} \\
(3.2070)\end{array}$ & $\begin{array}{c}0.0021 \\
(1.6263)\end{array}$ \\
\hline CashtoAsset & $\begin{array}{c}0.0183^{* * *} \\
(3.0221)\end{array}$ & $\begin{array}{c}0.0207^{* * *} \\
(4.4019)\end{array}$ & $\begin{array}{c}0.0104 \\
(1.3972)\end{array}$ & $\begin{array}{c}0.0129 \\
(1.5691)\end{array}$ & $\begin{array}{l}0.0142 * \\
(1.7491)\end{array}$ & $\begin{array}{c}0.0141 \text { ** } \\
(1.9780)\end{array}$ \\
\hline DebttoAsset & $\begin{array}{c}-0.0132 * * * \\
(-6.5959)\end{array}$ & $\begin{array}{c}-0.0143^{* * *} \\
(-4.2635)\end{array}$ & $\begin{array}{c}-0.0437^{* * *} \\
(-4.0542)\end{array}$ & $\begin{array}{c}-0.0418^{* * *} \\
(-3.6732)\end{array}$ & $\begin{array}{c}-0.0401 * * * \\
(-3.5732)\end{array}$ & $\begin{array}{c}-0.0261^{* * *} \\
(-2.6100)\end{array}$ \\
\hline $\mathrm{R} \& \mathrm{D} /$ Asset & $\begin{array}{c}-0.0398 \\
(-1.2070)\end{array}$ & $\begin{array}{c}-0.0597 \\
(-1.5620)\end{array}$ & $\begin{array}{c}-0.0662 \\
(-1.3502)\end{array}$ & $\begin{array}{c}-0.0747 \\
(-1.2357)\end{array}$ & $\begin{array}{c}-0.0207 \\
(-0.3882)\end{array}$ & $\begin{array}{c}0.0004 \\
(0.0067)\end{array}$ \\
\hline Intercept term & $\begin{array}{c}-0.4390 * * * \\
(-4.2852)\end{array}$ & $\begin{array}{c}-0.4730^{* * *} \\
(-3.6227)\end{array}$ & $\begin{array}{c}-0.5688^{* * *} \\
(-3.8092)\end{array}$ & $\begin{array}{c}-0.5893 \text { *** } \\
(-3.6916)\end{array}$ & $\begin{array}{c}-0.5287^{* * *} \\
(-3.1770)\end{array}$ & $\begin{array}{c}-0.5601^{* * *} \\
(-2.7302)\end{array}$ \\
\hline Sample size & 51,287 & 43,935 & 38,180 & 33,198 & 28,888 & 23,888 \\
\hline $\mathrm{R}^{2}$ & 0.098 & 0.118 & 0.121 & 0.145 & 0.119 & 0.168 \\
\hline Adjusted $\mathrm{R}^{2}$ & 0.0563 & 0.0752 & 0.0754 & 0.0985 & 0.0705 & 0.121 \\
\hline
\end{tabular}

All of the models control the individual and year-quarter fixed effects; ${ }^{* * *}, * *$, and ${ }^{*}$ indicate statistical significance at $1 \%, 5 \%$, and $10 \%$ respectively; the robust t-statistic adjusted for clustering by firm is indicated inside the parentheses. 


\section{Conclusions}

It is the consensus of existing research studies that the total factor productivity (TFP) is the core driving force for the sustainable and steady growth of individual firms and the overall economy. Many literatures have studied the economic and financial determinants of TFP, but few of them have investigated whether the informative stock price will have an impact on TFP. Whether these trading activities and stock price informativeness affect the listed firm's total factor productivity (TFP) in China is still a question that remains to be solved. In this paper, we empirically examined whether more informative stock prices are associated with higher listed manufacturing firms' TFP.

We believe that stock price informativeness may affect total factor productivity in two aspects. First, stock prices include information that managers do not know, such as information about future investment and growth opportunities; managers can learn this new information to improve their production process and technology $[3,50,51]$, and thus consequently increase their firm's TFP. Second, more informative stock prices may help stockholders monitor managers better, which mitigates the agency problem or alleviates the empire-building problem [7], and finally improves the TFP.

Using a sample of Chinese listed manufacturing firms over the period from 2007 to 2017, we show that the stock price informativeness (i.e., average lagged stock price nonsynchronicity or turnover rate) can significantly improve the total factor productivity. This finding remains robust when we address the endogeneity of stock price nonsynchronicity or turnover rate, using the average lagged value (from the previous year to the previous six years) as the independent variable to alleviate the two-way causal effects and using the individual-time fixed-effect model to mitigate the omitted variable problem. When we use the ROA as an alternative proxy for firm's productivity, the quantitative relation still remains the same. This result is consistent with the view that managers can learn new information to improve their decision making, leading to a more efficient productivity. Also, this result is consistent with the conjecture that stock price informativeness is associated with the higher monitoring of managers [7].

The conclusions above have important implications for governments and firms. The stock market is not only a place for generating information, but also delivers information to listed companies through feedback effects, and affects listed firm's real business activities and technological level, which has an irreplaceable role in the sustainable development of enterprises. Stock market information can improve the listed firms' total factor productivity, which is important for the sustainable development of firms. In consideration of the short development history of the Chinese stock market, whose information quality and efficiency is not as mature as that of developed countries, the Chinese government and listed companies should take steps to strengthen the information efficiency of the stock market, reinforce the information disclosure of listed companies, and take advantage of traders' information contained in stock price.

First, it is necessary for the Chinese government to improve the information disclosure system of the listed companies. A better information disclosure system can increase decision-related information for investors and mitigate information asymmetry problems, and hence reduce the cost of capital and improve the efficiency of resource allocation in the capital market. In addition, the information disclosure system enables the stock analysts to delve more information of the listed companies, which increases the stock price informativeness. Second, measures should be taken to develop institutional investors in China. Institutional investors are important participators in the stock market, who have substantial market power in gathering and interpreting information related to listed firms. They have considerable advantage in monitoring corporate activities compared to other investors, and contribute to alleviating information asymmetry. Since institutional investors play an important role in promoting corporate transparency, the development of institutional investors can help improve the information efficiency of the Chinese stock market. 
Third, from the perspective of companies, efforts should be made to enhance the corporate governance such as establishing an efficient ownership structure, improving the board governance, and implementing management incentives. On one hand, reasonable corporate governance helps constrain large shareholders or managers from seeking private interests, and reduce the damage of their tunneling behavior to shareholders' interests. On the other hand, it weakens the entrenchment effect of major shareholders or managers, increases the transparency of information, and reduces the cost of investors to collect information. So, better corporate governance may amplify the effect of stock price informativeness on firm's TFP.

Several limitations of this study should be acknowledged. First, our paper is limited in that we only studied the manufacturing listed firms in our sample. Although the listed manufacturing firm's TFP will be improved by the stock price informativeness, whether the non-manufacturing listed firms or non-listed firms will be affected by the stock price informativeness is still an open question. Our conclusion above is contained to the listed manufacturing firms. Second, we do not study what kinds of factors can improve the information-productivity sensitivity. Our paper just answers the question that the Chinese stock price informativeness has a positive impact on the listed manufacturing firms. However, we do not know under what type of information environment the information-productivity sensitivity is larger or smaller. Does a firm's characteristics, financial flexibility, financial constraints, or corporate governance affect the information-productivity sensitivity? It is still an open issue that remains to be solved.

For further research studies, we suggest three directions: First, we suggest extending our research sample to non-manufacturing listed firms including the financial sector or service sector. This extension will need a different method to estimate the productivity in the financial and service sector. Second, we could extend our sample to non-listed companies to study whether the information is still helpful for the managers of non-listed firms. Third, it is really worthwhile to investigate the determinants of the information-productivity sensitivity. If we know the factors that affect the information-productivity sensitivity, it is applicable for the government and companies to take steps to take better advantage of the stock market information.

Author Contributions: Conceptualization, F.J. and Q.F.; Methodology, F.L.; Software, F.L.; Validation, F.L., Q.F. and Q.W.; Formal Analysis, F.L.; Investigation, Q.F.; Resources, Q.F.; Data Curation, F.L.; Writing-Original Draft Preparation, Q.W.; Writing-Review \& Editing, F.L.; Visualization, F.L.; Supervision, Q.F.; Project Administration, Q.F.; Funding Acquisition, Q.F.

Funding: This research received no external funding.

Conflicts of Interest: The authors declare no conflict of interest.

\section{Appendix A}

Table A1. Data sources.

\begin{tabular}{|c|c|c|}
\hline Data & Time & Data Sources \\
\hline Daily stock market capitalization & 1991-2017 & $\begin{array}{l}\text { CSMAR Financial Database/Data Center/Stock } \\
\text { Market Series/Stock Market Trading/Daily Stock } \\
\text { Return File }\end{array}$ \\
\hline Daily individual stock return & 1991-2017 & $\begin{array}{l}\text { CSMAR Financial Database/Data Center/Stock } \\
\text { Market Series/Stock Market Trading/Daily Stock } \\
\text { Return File }\end{array}$ \\
\hline $\begin{array}{l}\text { Accounts payable } \\
\text { (annual, quarterly) }\end{array}$ & 1999-2017 & $\begin{array}{l}\text { CSMAR Financial Database/Data } \\
\text { Center/Corporate Research Series/Financial } \\
\text { Statements/Balance Sheets }\end{array}$ \\
\hline $\begin{array}{l}\text { Property Plant and Equipment } \\
\text { (annual, quarterly) }\end{array}$ & 2000-2017 & $\begin{array}{l}\text { CSMAR Financial Database/Data } \\
\text { Center/Corporate Research Series/Financial } \\
\text { Statements/Balance Sheets }\end{array}$ \\
\hline
\end{tabular}


Table A1. Cont.

\begin{tabular}{|c|c|c|}
\hline Data & Time & Data Sources \\
\hline Inventory (annual, quarterly) & 1999-2017 & $\begin{array}{l}\text { CSMAR Financial Database/Data } \\
\text { Center/Corporate Research Series/Financial } \\
\text { Statements/Balance Sheets } \\
\text { CSMAR Financial Database/Data }\end{array}$ \\
\hline Cash (annual, quarterly) & 1999-2017 & $\begin{array}{l}\text { Center/Corporate Research Series/Financial } \\
\text { Statements/Balance Sheets } \\
\text { CSMAR Financial Database/Data }\end{array}$ \\
\hline Total assets (annual, quarterly) & 1999-2017 & $\begin{array}{l}\text { Center/Corporate Research Series/Financial } \\
\text { Statements/Balance Sheets }\end{array}$ \\
\hline $\begin{array}{l}\text { Total liabilities } \\
\text { (annual, quarterly) }\end{array}$ & 1999-2017 & $\begin{array}{l}\text { CSMAR Financial Database/Data } \\
\text { Center/Corporate Research Series/Financial } \\
\text { Statements/Balance Sheets } \\
\text { CSMAR Financial Database/Data }\end{array}$ \\
\hline Sales revenue (annual, quarterly) & 1999-2017 & $\begin{array}{l}\text { Center/Corporate Research Series/Financial } \\
\text { Statements/Profit Statement }\end{array}$ \\
\hline $\begin{array}{l}\text { Operating profit } \\
\text { (annual, quarterly) }\end{array}$ & 1999-2017 & $\begin{array}{l}\text { CSMAR Financial Database/Data } \\
\text { Center/Corporate Research Series/Financial } \\
\text { Statements/Profit Statement }\end{array}$ \\
\hline $\begin{array}{l}\text { R\&D investment } \\
\text { (annual, quarterly) }\end{array}$ & 2007-2017 & $\begin{array}{l}\text { CSMAR Financial Database/Data } \\
\text { Center/Corporate Research Series/R \& D } \\
\text { Innovation of Listed Companies/R\&D situation }\end{array}$ \\
\hline $\begin{array}{l}\text { Cash paid for goods and services } \\
\text { (year, quarterly) }\end{array}$ & 1999-2017 & $\begin{array}{l}\text { CSMAR Financial Database/Data } \\
\text { Center/Corporate Research Series/Financial } \\
\text { Statements/Cash Flow Statement } \\
\text { CSMAR Financial Database/Data }\end{array}$ \\
\hline Tobin Q Value (year, quarterly) & 1991-2017 & $\begin{array}{l}\text { Center/Corporate Research Series/Financial } \\
\text { Index Analysis/Relative Value Index } \\
\text { Oxford Economics, downloaded using }\end{array}$ \\
\hline GDP deflator (annual, quarterly) & 1999-2017 & $\begin{array}{l}\text { DataStream under the codes CHXPGDP. and } \\
\text { CHXPGDP.F. }\end{array}$ \\
\hline $\begin{array}{l}\text { Investment price deflator } \\
\text { (annual, quarterly) }\end{array}$ & 1999-2017 & $\begin{array}{l}\text { Oxford Economics, downloaded using } \\
\text { DataStream. CHXPIFP. and CHXPIFP.F. }\end{array}$ \\
\hline $\begin{array}{l}\text { Total number of employees } \\
\text { (annual, quarterly) }\end{array}$ & 2001-2017 & Wind database/Corporate Basic Information \\
\hline Annual turnover rate (annual) & 1999-2017 & $\begin{array}{l}\text { RESSET Database / RESSET Stock/Turnover } \\
\text { Rate/Annual Turnover Rate }\end{array}$ \\
\hline $\begin{array}{l}\text { Quarterly turnover rate } \\
\text { (quarterly) }\end{array}$ & 1999-2017 & $\begin{array}{l}\text { RESSET Database/RESSET Stock/Turnover } \\
\text { Rate/quarterly Turnover Rate }\end{array}$ \\
\hline
\end{tabular}

Table A2. Meaning of variables.

\begin{tabular}{|c|c|}
\hline Variables & Meaning \\
\hline tfp_fe & $\begin{array}{l}\text { Represents an annual or quarterly TFP. It is estimated by individual and time fixed effect } \\
\text { method. }\end{array}$ \\
\hline \multirow{3}{*}{ PSI } & $\begin{array}{l}\text { Represents the annual or quarterly stock price nonsynchronicity. Use the annual or } \\
\text { quarterly data to obtain the } \mathrm{R}_{\mathrm{i}}^{2} \text { of the regression equation: }\end{array}$ \\
\hline & $\mathrm{r}_{\mathrm{ijt}}=\alpha_{\mathrm{i} 0}+\alpha_{\mathrm{i} 1} \mathrm{r}_{\mathrm{mt}}+\alpha_{\mathrm{i} 2} \mathrm{r}_{\mathrm{jt}}+\varepsilon_{\mathrm{ijt}}$, and then calculate PSI $\mathrm{i}=\ln \left(\frac{1-\mathrm{R}_{\mathrm{i}}^{2}}{\mathrm{R}_{\mathrm{i}}^{2}}\right)$. where $\mathrm{i}$ is for firm $\mathrm{i}$, \\
\hline & $\begin{array}{l}j \text { is for industry } j \text {, and } t \text { is for day } t, r_{i j t} \text { is the stock return of firm } i \text { in industry } j \text { on day } t \text {, } \\
r_{m t} \text { is the value weighted market return on day } t \text {, and } r_{j t} \text { is the value weighted industry } \\
\text { return on day } t \text {. The weights are based on market capitalization. (This article uses the } \\
\text { 3-digit industry). }\end{array}$ \\
\hline $\log Y r T r d T u r n R$ & $\begin{array}{l}\text { Represents the logarithmic value of the annual turnover rate of tradable shares, which is } \\
\text { equal to the sum of the daily turnover rate in the current year. }\end{array}$ \\
\hline
\end{tabular}


Table A2. Cont.

\begin{tabular}{cl}
\hline Variables & \multicolumn{1}{c}{ Meaning } \\
\hline $\log$ QrTrdTurnR & $\begin{array}{l}\text { Represents the logarithmic value of quarterly turnover rate of the tradable shares, which } \\
\text { is calculated as the sum of the daily turnover of the tradable shares in the quarter. }\end{array}$ \\
\hline logAsset & $\begin{array}{l}\text { Represents the logarithmic value of the total assets of the listed company at the end of } \\
\text { the year or the quarter. }\end{array}$ \\
Tobin'sQ & $\begin{array}{l}\text { Uses the annual or quarter Tobin q value in the CSMAR Financial Database, which is } \\
\text { equal to the market value divided by total asset. } \\
\text { Cash at the end of the year (end of quarter) divided by total assets at the end of the year } \\
\text { (end of quarter). }\end{array}$ \\
\hline Debt/Asset & $\begin{array}{l}\text { Total liabilities at the end of the year (end of quarter) divided by the total assets at the } \\
\text { end of the year (end of season). }\end{array}$ \\
\hline R\&D/Asset & $\begin{array}{l}\text { R\&D investment at the end of the year (end of quarter) divided by total assets at the } \\
\text { end of the year (end of quarter). The data of annual R\&D investment using R\&D } \\
\text { investment amount in the CSMAR Financial Database, converting the missing value to 0; } \\
\text { and the data of quarterly R\&D investment using quarterly R\&D expenditure in the } \\
\text { CSMAR Financial Database. }\end{array}$ \\
\hline ROA & $\begin{array}{l}\text { The operating profit at the end of the year divided by the total assets at the beginning of } \\
\text { the year; the operating profit at the end of the quarter divided by total assets at the } \\
\text { beginning of the quarter. }\end{array}$ \\
\hline
\end{tabular}

\section{References}

1. Bond, P.; Edmans, A.; Goldstein, I. The Real Effects of Financial Markets. J. Financ. 2012, 67, 933-971.

2. Fama, E.F. Efficient Capital Markets: A Review of Theory and Empirical Work. J. Financ. 1970, $25,383-417$. [CrossRef]

3. Luo, Y. Do Insiders Learn from Outsiders? Evidence from Mergers and Acquisitions. J. Financ. 2005, 60, 1951-1982. [CrossRef]

4. Ben-Nasr, H.; Alshwer, A.A. Does stock price informativeness affect labor investment efficiency? J. Corp. Financ. 2016, 38, 249-271. [CrossRef]

5. Durnev, A.; Morck, R.; Yeung, B. Value-enhancing capital budgeting and firm-specific stock return variation. J. Financ. 2004, 59, 65-105. [CrossRef]

6. Edmans, A.; Jayaraman, S.; Schneemeier, J. The Source of Information in Prices and Investment-Price Sensitivity. J. Financ. Econ. 2017, 126, 74-96. [CrossRef]

7. Ferreira, D.; Ferreira, M.A.; Raposo, C.C. Board structure and price informativeness. J. Financ. Econ. 2011, 99, 523-545. [CrossRef]

8. Solow, R.M. Technical Change and the Aggregate Production Function. Rev. Econ. Stat. 1957, 39, $554-562$. [CrossRef]

9. Morck, R.; Yeung, B.; Yu, W. The information content of stock markets: Why do emerging markets have synchronous stock price movements? J. Financ. Econ. 2000, 58, 215-260. [CrossRef]

10. Jin, L.; Myers, S.C. $\mathrm{R}^{2}$ around the world: New theory and new tests. J. Financ. Econ. 2006, 79, $257-292$. [CrossRef]

11. Roll, R. R ${ }^{2}$. J. Financ. 1988, 43, 541-566. [CrossRef]

12. Bennett, B.; Stulz, R.; Wang, Z. Does the Stock Market Make Firms More Productive? National Bureau of Economic Research: Cambridge, MA, USA, 2017.

13. Chae, J. Trading Volume, Information Asymmetry, and Timing Information. J. Financ. 2005, 60, 413-442. [CrossRef]

14. Ferreira, M.A.; Laux, P.A. Corporate Governance, Idiosyncratic Risk, and Information Flow. J. Financ. 2007, 62, 951-989. [CrossRef]

15. Holmström, B.; Tirole, J. Market liquidity and performance monitoring. J. Polit. Econ. 1993, 101, 678-709.

16. Morck, R.; Shleifer, A.; Vishny, R.W.; Shapiro, M.; Poterba, J.M. The Stock Market and Investment: Is the Market a Sideshow? Brook. Pap. Econ. Act. 1990, 1990, 157-215. [CrossRef] 
17. Chen, Q.; Goldstein, I.; Jiang, W. Price Informativeness and Investment Sensitivity to Stock Price. Rev. Financ. Stud. 2007, 20, 619-650. [CrossRef]

18. Wasserman, N.; Nohria, N.; Anand, B.N. When Does Leadership Matter? The Contingent Opportunities View of CEO Leadership; SSRN[R]; HBS Working Paper 02-04; Harvard Business School: Boston, MA, USA, 2001.

19. Bertrand, M.; Schoar, A. Managing with Style: The Effect of Managers on Firm Policies. Q. J. Econ. 2003, 118, 1169-1208. [CrossRef]

20. Bloom, N.; Van Reenen, J. Measuring and Explaining Management Practices Across Firms and Countries. Q. J. Econ. 2007, 122, 1351-1408. [CrossRef]

21. Bloom, N.; Eifert, B.; Mahajan, A.; McKenzie, D.; Roberts, J. Does Management Matter? Evidence from India. Q. J. Econ. 2013, 128, 1-51. [CrossRef]

22. Denison, E.F. Education, Economic Growth, and Gaps in Information. J. Polit. Econ. 1962, 70, $124-128$. [CrossRef]

23. Jorgenson, D.W.; Gollop, F.M.; Fraumeni, B.M. Productivity and U.S. economic growth. Econ. J. 1987, 100, 274.

24. Hellerstein, J.K.; Neumark, D.; Troske, K.R. Wages, Productivity, and Worker Characteristics: Evidence from Plant-Level Production Functions and Wage Equations. J. Labor Econ. 1999, 17, 409-446. [CrossRef]

25. Abowd, J.M.; Haltiwanger, J.; Jarmin, R.; Lane, J.; Lengermann, P.; McCue, K.; McKinney, K.; Sandusky, K. The Relation among Human Capital, Productivity, and Market Value: Building Up from Micro Evidence; Nber Chapters; National Bureau of Economic Research: Cambridge, MA, USA, 2009; pp. 153-204.

26. Fox, J.T.; Smeets, V. Does input quality drive measured differences in firm productivity? Int. Econ. Rev. 2011, 52, 961-989. [CrossRef]

27. Cohen, W.M.; Levinthal, D.A. Innovation and Learning: The Two Faces of R \& D. Econ. J. 1989, 99, $569-596$.

28. Aw, B.Y.; Roberts, M.J.; Xu, D.Y. R \& D Investment, Exporting, and Productivity Dynamics. Am. Econ. Rev. 2011, 101, 1312-1344.

29. Doraszelski, U.; Jaumandreu, J. R \& D and Productivity: Estimating Endogenous Productivity. Rev. Econ. Stud. 2013, 80, 1338-1383.

30. Gatti, R.; Love, I. Does access to credit improve productivity? Evidence from Bulgaria. Econ. Transit. 2008, 16, 445-465. [CrossRef]

31. Butler, A.W.; Cornaggia, J. Does access to external finance improve productivity? Evidence from a natural experiment. J. Financ. Econ. 2011, 99, 184-203. [CrossRef]

32. Levine, R. Financial Development and Economic Growth: Views and Agenda. J. Econ. Lit. 1997, 35, 688-726.

33. Levine, R.; Zervos, S. Stock Markets, Banks, and Economic Growth. Am. Econ. Rev. 2000, 88, 537-558.

34. Beck, T.; Demirguc-Kunt, A.S.; Laeven, L.; Levine, R. Finance, Firm Size, and Growth. J. Money Credit. Bank. 2008, 40, 1379-1405. [CrossRef]

35. Jones, D.C.; Kato, T. The Productivity Effects of Employee Stock-Ownership Plans and Bonuses: Evidence from Japanese Panel Data. Am. Econ. Rev. 1995, 85, 391-414.

36. Ittner, C.D.; Lambert, R.A.; Larcker, D.F. The structure and performance consequences of equity grants to employees of new economy firms. J. Account. Econ. 2003, 34, 89-127. [CrossRef]

37. Kim, E.H.; Paige, O. Broad-Based Employee Stock Ownership: Motives and Outcomes. J. Financ. 2014, 69, 1273-1319. [CrossRef]

38. Barth, E.; Gulbrandsen, T.; Schønea, P. Family ownership and productivity: The role of owner-management. J. Corp. Financ. 2005, 11, 107-127. [CrossRef]

39. Brav, A.; Jiang, W.; Kim, H. The real effects of hedge fund activism: Productivity, asset allocation, and labor outcomes. Rev. Financ. Stud. 2015, 28, 2723-2769. [CrossRef]

40. Hayek, F.A. The use of knowledge in society. Am. Econ. Rev. 1945, 35, 519-530.

41. Fishman, M.J.; Hagerty, K.M. Insider trading and the efficiency of stock prices. South China J. Econ. 1992, 23, 106-122. [CrossRef]

42. Leland, H.E. Insider trading: Should it be prohibited? J. Polit. Econ. 1992, 100, 859-887. [CrossRef]

43. Khanna, N.; Slezak, S.L.; Bradley, M. Insider trading, outside search, and resource allocation: Why firms and society may disagree on insider trading restrictions. Rev. Financ. Stud. 1994, 7, 575-608. [CrossRef]

44. Bernhardt, D.; Hollifield, B.; Hughson, E. Investment and insider trading. Rev. Financ. Stud. 1995, 8, 501-543. [CrossRef] 
45. Dow, J.; Gorton, G. Stock Market Efficiency and Economic Efficiency: Is There a Connection? J. Financ. 1997, 52, 1087-1129. [CrossRef]

46. Boot, A.W.; Thakor, A.V. Financial system architecture. Rev. Financ. Stud. 1997, 10, 693-733. [CrossRef]

47. Subrahmanyam, A.; Titman, S. The Going-Public Decision and the Development of Financial Markets. J. Financ. 1999, 54, 1045-1082. [CrossRef]

48. Bakke, T.; Whited, T.M. Which firms follow the market? An analysis of corporate investment decisions. Rev. Financ. Stud. 2010, 23, 1941-1980. [CrossRef]

49. Foucault, T.; Gehrig, T. Stock Price Informativeness, Cross-Listings, and Investment Decisions; Elsevier: Amsterdam, The Netherlands, 2008; pp. 146-168.

50. Foucault, T.; Frésard, L. Cross-Listing, Investment Sensitivity to Stock Price, and the Learning Hypothesis; Social Science Electronic Publishing: Rochester, NY, USA, 2012; Volume 25, pp. 3305-3350.

51. Foucault, T.; Fresard, L. Learning from peers' stock prices and corporate investment. J. Financ. Econ. 2014, 111, 554-577. [CrossRef]

52. Ozoguz, A.; Rebello, M.J. Investment and Peer Firms' Stock Prices. SSRN Electron. J. 2013. [CrossRef]

53. Zuo, L. The informational feedback effect of stock prices on management forecasts. J. Account. Econ. 2016, 61, 391-413. [CrossRef]

54. Bennett, B.; Garvey, G.T.; Milbourn, T.T.; Wang, Z. Managerial Compensation and Stock Price Informativeness; Elsevier: Amsterdam, The Netherlands, 2018.

55. Schoar, A. Effects of Corporate Diversification on Productivity. J. Financ. 2002, 57, 2379-2403. [CrossRef]

56. Giannetti, M.; Liao, G.; Yu, X. The Brain Gain of Corporate Boards: Evidence from China. J. Financ. 2015, 70, 1629-1682. [CrossRef]

57. Marschak, J.; Andrews, W.H. Random simultaneous equations and the theory of production. Econometrica 1944, 13, 143-205. [CrossRef]

58. Tian, G.Y.; Twite, G. Corporate governance, external market discipline and firm productivity. J. Corp. Financ. 2011, 17, 403-417. [CrossRef]

59. Hsieh, C.; Klenow, P.J. Misallocation and manufacturing TFP in China and India. Q. J. Econ. 2009, 124, 1403-1448. [CrossRef]

60. İmrohoroğlu, A.; Tüzel, Ş. Firm-level productivity, risk, and return. Manag. Sci. 2014, 60, $2073-2090$. [CrossRef]

61. Levinsohn, J.; Petrin, A. Estimating production functions using inputs to control for unobservables. Rev. Econ. Stud. 2003, 70, 317-341. [CrossRef]

62. Ayyagari, M.; Demirgüç-Kunt, A.; Maksimovic, V. Formal versus informal finance: Evidence from China. Rev. Financ. Stud. 2010, 23, 3048-3097. [CrossRef]

63. Fang, H.; Nofsinger, J.R.; Quan, J. The effects of employee stock option plans on operating performance in Chinese firms. J. Bank. Financ. 2015, 54, 141-159. [CrossRef]

64. Blume, L.; Easley, D.; O’Hara, M. Market statistics and technical analysis: The role of volume. J. Financ. 1994, 49, 153-181. [CrossRef]

(C) 2019 by the authors. Licensee MDPI, Basel, Switzerland. This article is an open access article distributed under the terms and conditions of the Creative Commons Attribution (CC BY) license (http:// creativecommons.org/licenses/by/4.0/). 